\title{
PERANCANGAN DAN PEMBUATAN APLIKASI PERENCANAAN AGENDA PEGAWAI UNS BERBASIS FRAMEWORK YII2 TERINTEGRASI DENGAN API UNS
}

\author{
Yudho Yudhanto \\ Fakultas MIPA, Program Studi D3 Teknik Informatika \\ Universitas Negeri Sebelas Maret \\ Email: yuda@mipa.uns.ac.id \\ Itabella Kurniasari \\ Fakultas MIPA, Program Studi D3 Teknik Informatika \\ Universitas Negeri Sebelas Maret \\ Email: itabellakurniasari@student.uns.ac.id
}

\begin{abstract}
ABSTRAK
Dari data jumlah pegawai di simpeg.uns.ac.id didapatkan data pegawai PNS dan Non PNS sebanyak 3169. Dengan rincian pendidik PNS sebanyak 1435, pendidikan Non PNS sebanyak 153, kependidikan PNS sebanyak 963, dan kependidikan Non PNS sebanyak 618. Sedangkan jumlah ruangan di UNS per unit kurang dari 10 ruangan.

Implementasi aplikasi sistem perencanaan agenda pegawai sistem ini dapat memeberikan solusi yaitu dapat mempermudah anggota rapat untuk mengetahui agenda rapat yang harus dihadiri dan mendapat pemberitahuan melalui sms broadcast dengan aplikasi web berbasis framework Yii2 dan sms broadcast dengan menggunakan API UNS .
\end{abstract}

Kata kunci: Aplikasi, Agenda, Pegawai, yii2, website, Framework, SMS, Broadcast.

\section{ABSTRACT}

From the data in simpeg.uns.ac.id Term employees obtained the data civil servants and non-civil servants as much as 3169. Article Search Google PAID many as 1,435 civil servants Educator, Education Non PNS many as 153, as many as 963 education civil servants, and education as Non PNS 618. While period rooms at UNS per unit of less than 10 rooms.

Implementation Planning System Application System employees singer agenda can be memeberikan Namely Solutions can be makes it MEMBER meeting to review the agenda of the Meeting Must know attended and received notification sms broadcast through web-based application framework WITH Yii2 And sms broadcast WITH using API UNS.

Keywords: Applications, Employees, yii2, website, Framework, SMS, Broadcast.

\section{PENDAHULUAN}

Perkembangan teknologi informasi dan komunikasi saat ini telah mempengaruhi segala bidang. Hal tersebut dikarenakan teknologi informasi dibutuhkan dalam optimalisasi proses-proses yang ada dalam pelaksanaan kegiatan manusia. Tidak terkecuali dalam pelaksanaan agenda kegiatan pegawai di UNS (Universitas Sebelas Maret). Dari data jumlah pegawai di simpeg.uns.ac.id didapatkan data pegawai PNS dan Non PNS sebanyak 3169. Dengan rincian pendidik PNS sebanyak 1435, pendidikan Non PNS sebanyak 153, kependidikan PNS sebanyak 963, dan kependidikan Non PNS sebanyak 618. Sedangkan jumlah ruangan di UNS per unit kurang dari 10 ruangan.

Dalam penyusunan jadwal agenda rapat masih sering terkandala salah satunya pencatatan yang masih manual, baik pencatatan anggota, ruangan, maupun agenda rapat. Penyimpanan hasil rapat juga masih secara manual disimpan di komputer dan dimasukan kedalam satu folder. Pada pencatatan anggota yang terjadi pada saat ini adalah dilakuan pencatatan manual yang dilakukan di buku ataupun diinput secara 
manual ke komputer dengan menggunakan Microsoft excel atau dengan menggunakan Microsoft word, sehingga tidak mengetahui jelas anggota mana saja yang terdaftar dalam sebuah rapat. Sehingga harus melakukan pengecekan satu persatu untuk mengatahui rapat mana saja yang harus dihadiri oleh suatu anggota.

Sedangkan teknologi web sekarang ini sedang berkembang pesat, salah satunya jenis framework yang digunakan di Universitas Sebelas Maret yaitu framework YII. Framework ini memudahkan untuk developer dalam menyusun agenda pegawai. Agenda ini menggunakn web dengan dilengkapai dengan sms broadcast untuk peserta rapat untuk memudahkan dalam memberikan informasi kepada peserta rapat.

Kerena perbandingan jumlah pegawai dengan ruang di UNS dan waktu untuk rapat tidak seimbang oleh sebab itu untuk mengatasi masalah tentang perencanaan agenda pegawai sistem ini dapat memeberikan solusi yaitu dapat mempermudah anggota rapat untuk mengetahui agenda rapat yang harus dihadiri dan mendapat pemberitahuan melalui sms broadcast dengan aplikasi web berbasis framework Yii2 dan sms broadcast dengan menggunakan API UNS .

\section{METODOLOGI PENELITIAN}

Metode penelitian yang digunakan untuk menyelesaikan penelitian ini adalah prototyping models. Alur yang dilakukan adalah seperti gambar 1 berikut ini :

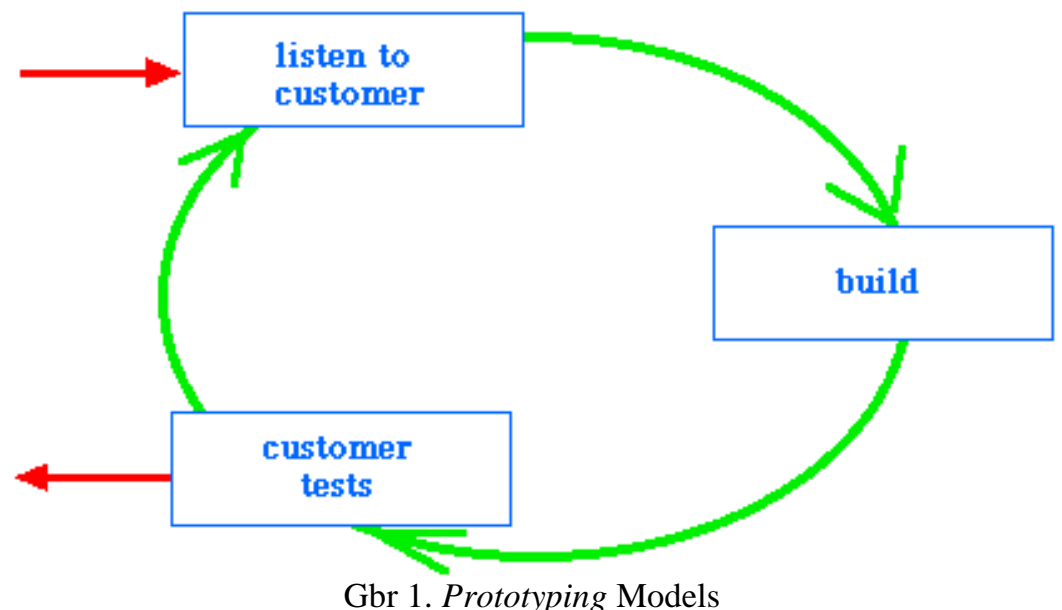

Kemudian untuk detail pelaksanaannya dibagai dalam beberapa tahap yakni seperti berikut ini :

\subsection{Wawancara}

Metode pengumpulan data dengan cara bertanya langsung kepada responden yang dilakukan secara sistematis dan berlandaskan kepada tujuan penelitian.

\subsection{Studi Pustaka}

Studi pustaka adalah metode pengumpulan data dengan membaca buku atau literatur literatur yang berhubungan dengan permasalahan yang dijadikan objek dalam penelitian.

2.3. Pengumpulan kebutuhan

Client dan penulis melakukan interaksi mendefinisikan format seluruh perangkat lunak, mengidentifikasikan semua kebutuhan dan garis besar aplikasi yang akan dibuat.

\subsection{Membangun prototyping}

Membangun prototyping dengan membuat perancangan sementara yang berfokus pada bentuk tampilan user interface yang nantinya akan diimplementasikan pada sistem.

2.5. Evaluasi prototyping 
Evaluasi dilakukan oleh client apakah prototyping sudah sesuai dengan keinginan client. Apabila sudah sesuai lanjut untuk pengkodean aplikasi, apabila tidak prototyping akan direvisi.

2.6. Pengkodean Sistem

Prototype yang sudah disepakati diterjemahkan dalam bentuk bahasa pemrograman yang sesuai, disini aplikasi menggunakan bahasa PHP.

2.7. Menguji Sistem

Pengujian dilakukan setelah aplikasi sudah siap dipakai. Pengujian menggunakan blackbox.

2.8. Evaluasi Sistem

Client dan penulis melakukan evaluasi apakah sistem yang dibangun sudah sesuai yang diharapkan. Jika ya maka sistem siap digunakan. Jika tidak maka direvisi lagi.

\section{HASIL DAN PEMBAHASAN}

\subsection{Proses Bisnis Aplikasi}

Aplikasi Perencanaan agenda menungkinkan user untuk menentukan perencanaan agenda pegawai sehingga pegawai tidak mempunyai agenda yang dilakukan dalam waktu bersamaan dan pegawai dapat mengetahi agenda apa saja yang sedang diikuti. Operator unit menginputkan data penanggung jawab dan agenda, kemudian peserta dapat agenda yang diikuti. Sedangkan untuk operator unit dapat melihat agenda. Pada saat operator unit melakukan broadcast sms ke peserta rapat maka peserta rapat dapat menerima sms untuk mengikuti rapat pada waktu tertentu dan ruang yang telah ditentukan.

\subsection{Use Case}

Use case agenda pegawai memiliki 3 aktor utama yaitu admin, operator unit, dan peserta. Pada masing masing actor memiliki tugas atau fungsi masing-masing. 


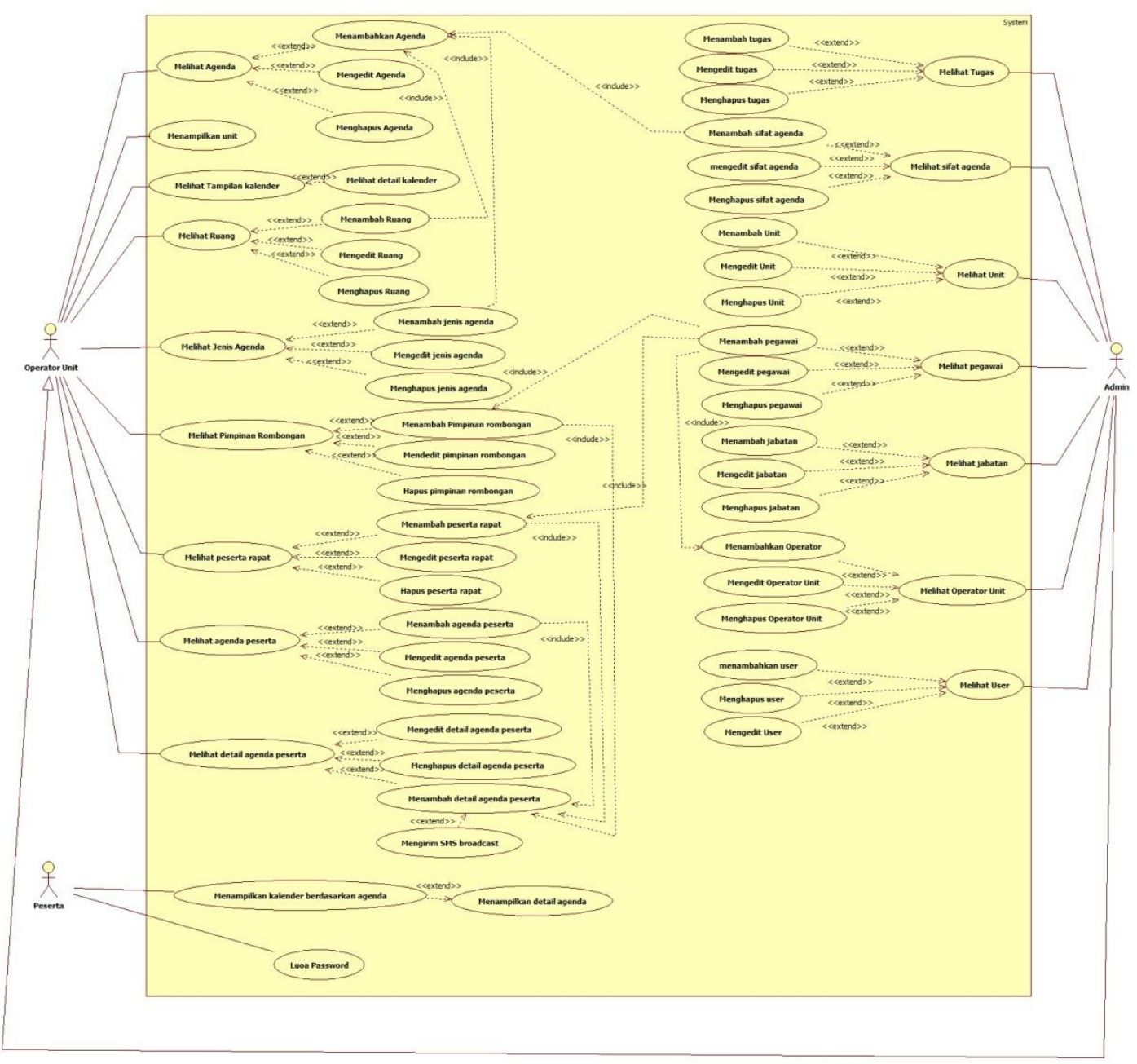

Gbr.2 Use Case Aplikasi Agenda Pegawai

\subsection{ERD}

Dari proses identifikasi aktor dalam use case, maka bisa dibuatlah ERD (Entity Relationship Diagram). Seperti yang terlihat dalam gambar 4. 


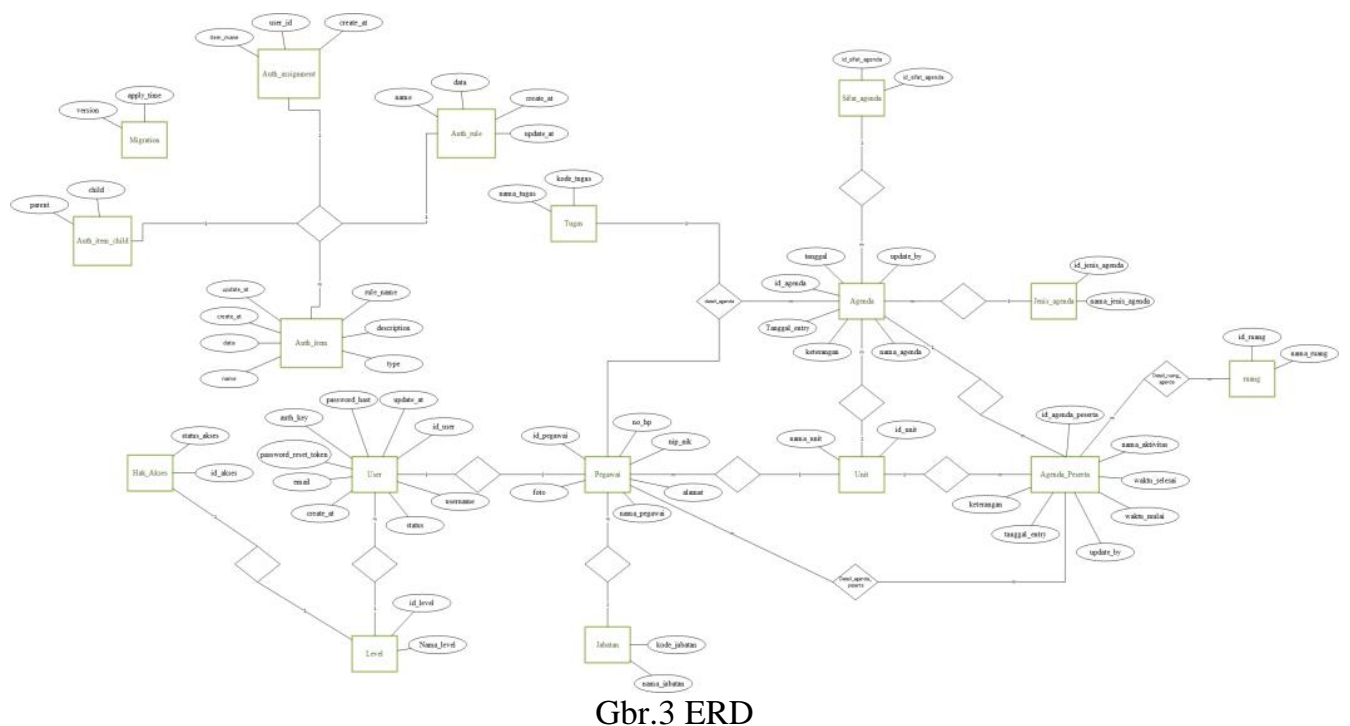

\subsection{Relasi Tabel}

Relasi antar tabel menjelaskan hubungan tabel satu dengan tabel yang lainnya apakah one to one, one to many, atau many to many ${ }^{[5]}$. Relasi tabel aplikasi ini dapat dilihat pada gambar 5.

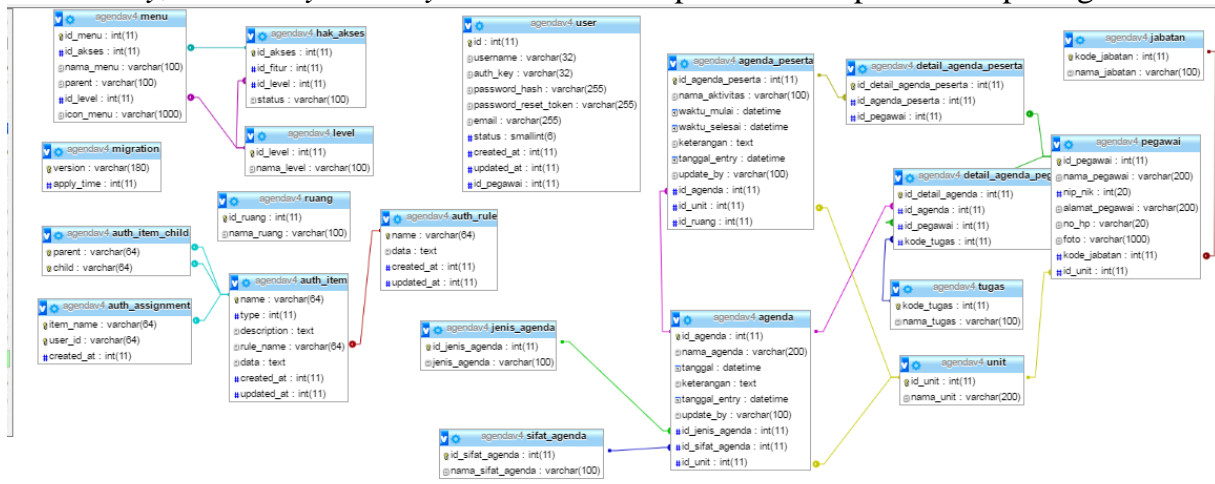

Gbr.4 Relasi Tabel agenda pegawai

\subsection{User Interface}

Perancangan desain user interface aplikasi

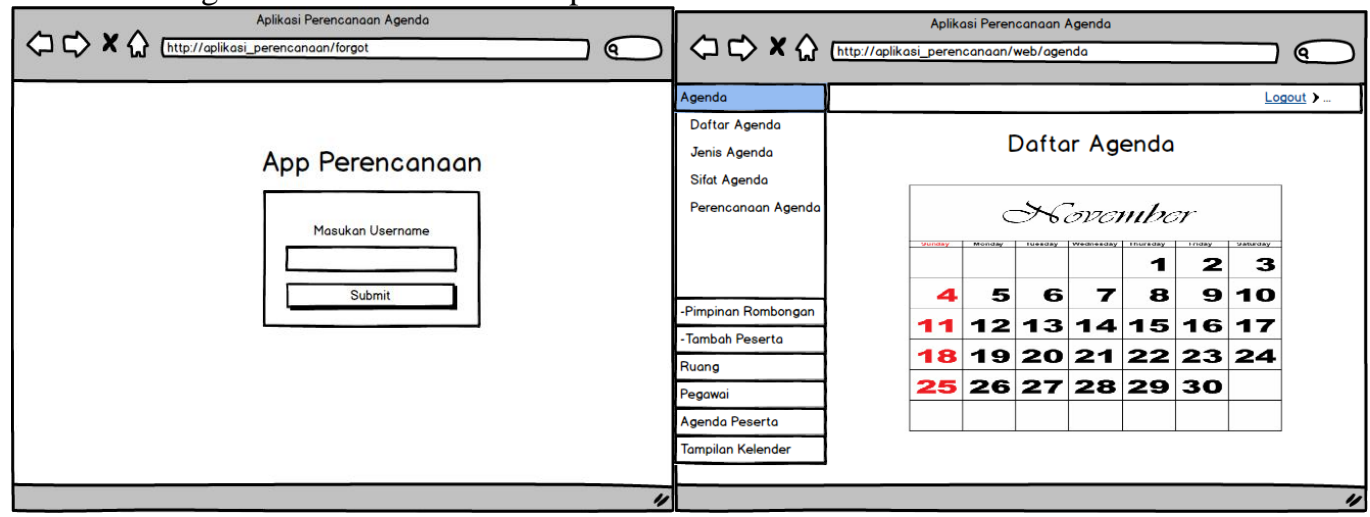

Gbr.5. Halaman Login dan dashboard 
Indonesian Journal of Applied Informatics, Vol. 1 No. 2 Mei 2017

ISSN: 2548-3846

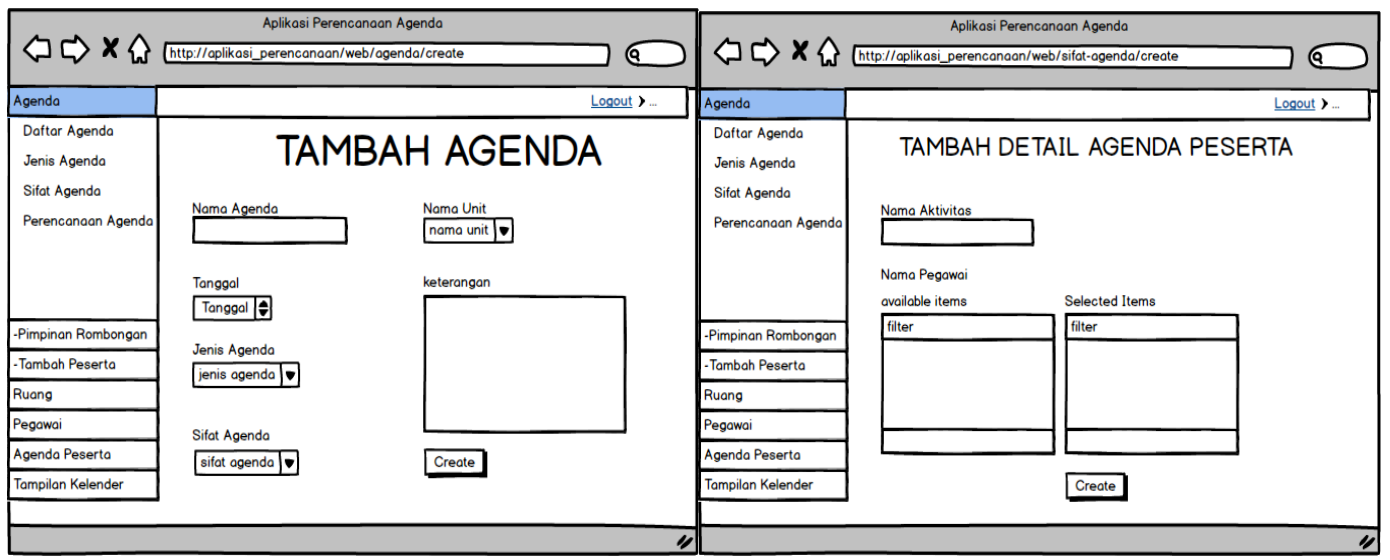

Gbr.6. Halaman tambah agenda dan tambah detail agenda peserta

Sedangkan implementasi rancangan desain dapat dilihat pada gambar 7, 8, 9 dan 10 :

$t \rightarrow$ C (i) agenda_pegawai:801/sitefforot

\section{AppPerencanaan}

Masukkan Username

Username

Submit

Gbr.7. Halaman Login 


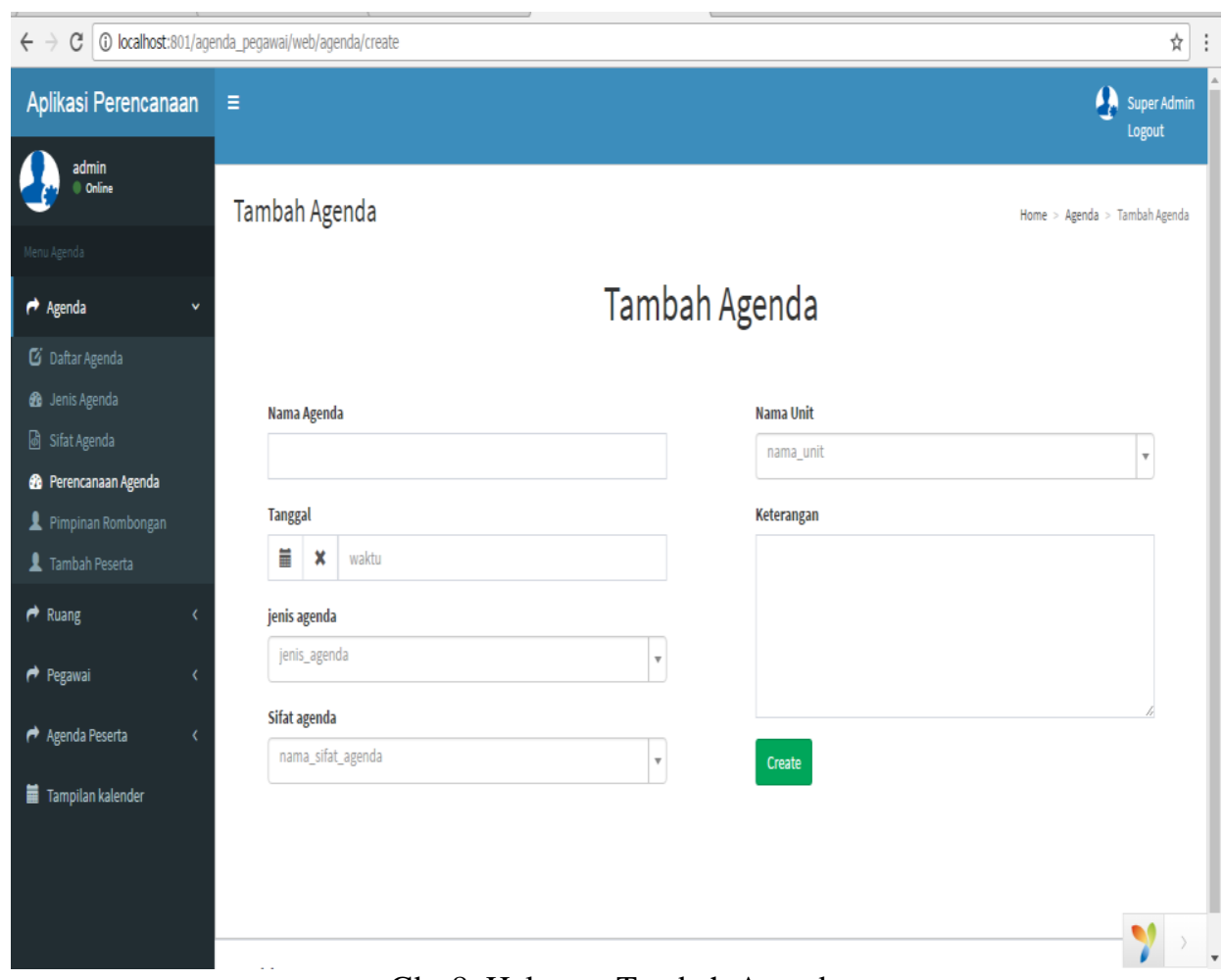

Gbr.8. Halaman Tambah Agenda

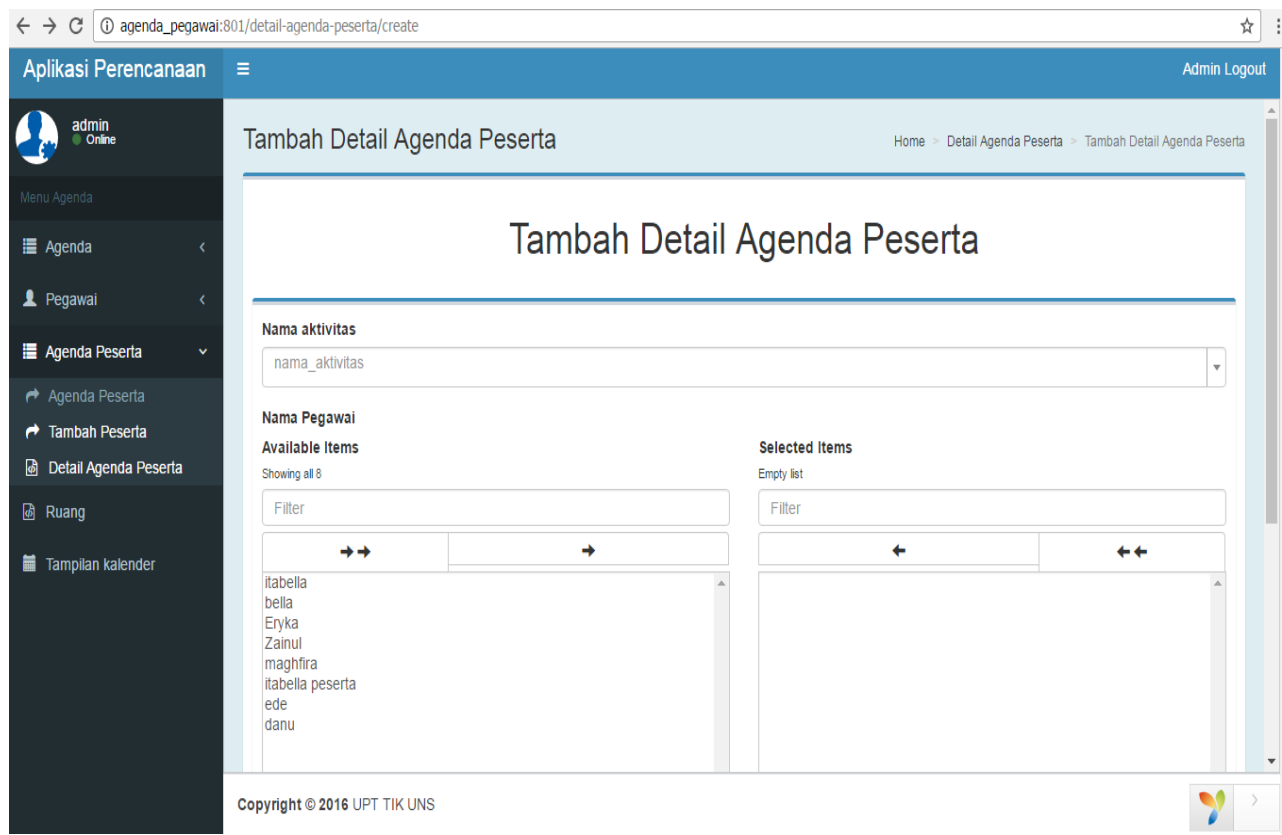

Gbr.9. Halaman Tambah Detail Agenda Peserta 


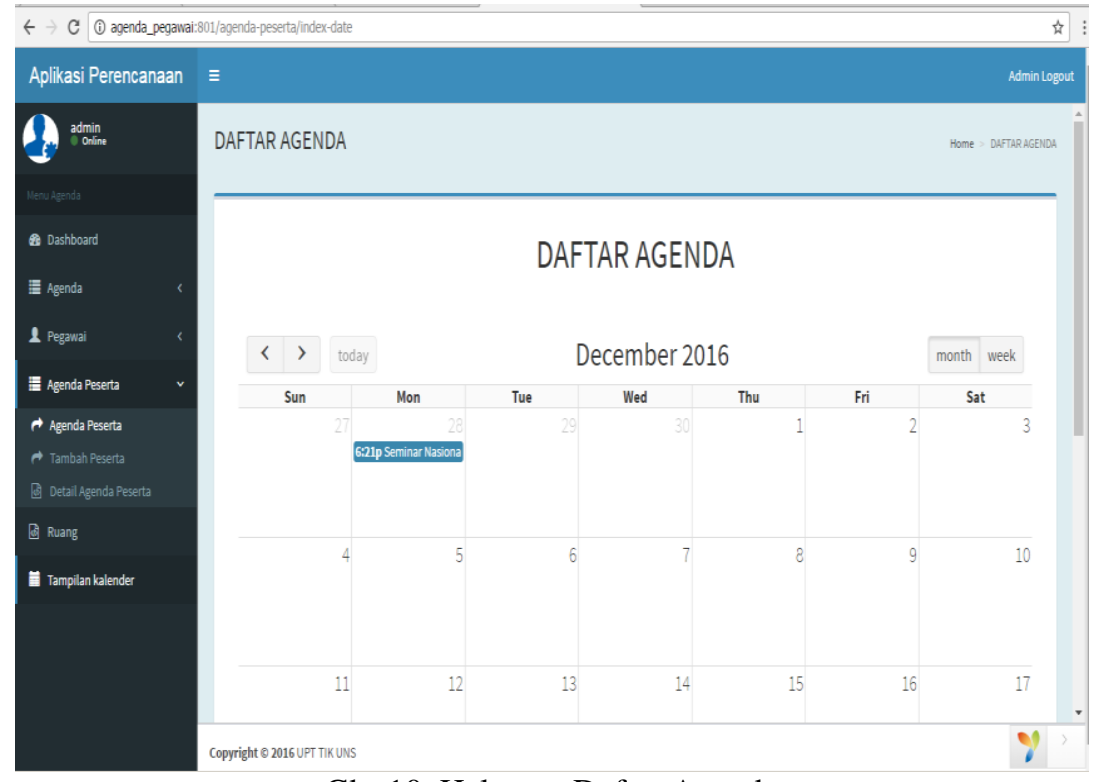

Gbr.10. Halaman Daftar Agenda

\subsection{Pengujian}

Pengujian sistem dilakukan dengan metode blackbox testing yaitu pengujian yang dilakukan dari segi spesifikasi fungsional tanpa menguji desain kode program. Berikut ini adalah beberapa pengujian dari 42 task pengujian seperti pada tabel dibawah ini.

\begin{tabular}{|c|c|c|c|c|}
\hline No. & Pengujian & Skenario & Indikator & Status \\
\hline 1. & Login & $\begin{array}{l}\text { Menampilkan form } \\
\text { login } \rightarrow \text { mengisi } \\
\text { username dan password }\end{array}$ & $\begin{array}{lr}\text { Apabila } & \text { dapat } \\
\text { masuk } & \text { sesuai } \\
\text { dengan } & \text { hak } \\
\text { aksesnya } & \\
\end{array}$ & Berhasil \\
\hline 2. & Membuat agenda & $\begin{array}{l}\text { Memilih menu daftar } \\
\text { agenda } \rightarrow \text { memilih } \\
\text { button create } \rightarrow \\
\text { mengisi semua data }\end{array}$ & $\begin{array}{l}\text { Apabila data } \\
\text { tersimpan di } \\
\text { database dan } \\
\text { dapat } \\
\text { menampilkan } \\
\text { datanya di view }\end{array}$ & Berhasil \\
\hline 3. & $\begin{array}{l}\text { Melakukan Edit } \\
\text { agenda }\end{array}$ & $\begin{array}{l}\text { Memilih menu daftar } \\
\text { agenda } \rightarrow \text { memilih icon } \\
\text { pensil } \rightarrow \text { melakukan edit } \\
\text { data }\end{array}$ & $\begin{array}{lr}\text { Apabila } & \text { data } \\
\text { berhasil di } & \text { edit } \\
\text { dan data } & \text { masuk } \\
\text { ke } & \text { dalam } \\
\text { database } & \end{array}$ & Berhasil \\
\hline 4. & Melakukan hapus & Memilih menu daftar & Apabila & Berhasil \\
\hline
\end{tabular}




\begin{tabular}{|c|c|c|c|c|}
\hline & agenda & $\begin{array}{l}\text { agenda } \rightarrow \text { memilih icon } \\
\text { hapus agenda }\end{array}$ & $\begin{array}{l}\text { berhasil di hapus } \\
\text { sesuai dengan id }\end{array}$ & \\
\hline 5. & $\begin{array}{l}\text { Memambahkan } \\
\text { jenis agenda }\end{array}$ & $\begin{array}{l}\text { Memilih menu jenis } \\
\text { agenda } \rightarrow \text { memilih } \\
\text { tombol } \\
\text { create } \rightarrow \text { memasukan } \\
\text { data }\end{array}$ & $\begin{array}{l}\text { Apabila data } \\
\text { berhasil } \\
\text { disimpan di } \\
\text { database }\end{array}$ & Berhasil \\
\hline 6. & $\begin{array}{l}\text { Melakukan jenis } \\
\text { agenda }\end{array}$ & $\begin{array}{l}\text { Memilih menu jenis } \\
\text { agenda } \rightarrow \text { memilih icon } \\
\text { pensil } \rightarrow \text { melakukan edit } \\
\text { data }\end{array}$ & $\begin{array}{l}\text { Apabila data } \\
\text { berhasil di edit } \\
\text { dan data masuk } \\
\text { ke dalam } \\
\text { database }\end{array}$ & Berhasil \\
\hline 7. & $\begin{array}{l}\text { Melakukan hapus } \\
\text { jenis agenda }\end{array}$ & $\begin{array}{l}\text { Memilih menu jenis } \\
\text { agenda } \rightarrow \text { memilih icon } \\
\text { hapus jenis agenda }\end{array}$ & $\begin{array}{l}\text { Apabila data } \\
\text { berhasil di hapus } \\
\text { sesuai dengan id }\end{array}$ & Berhasil \\
\hline 8. & $\begin{array}{l}\text { Memambahkan } \\
\text { sifat agenda }\end{array}$ & $\begin{array}{l}\text { Memilih menu sifat } \\
\text { agenda } \rightarrow \text { memilih } \\
\text { tombol } \\
\text { create } \rightarrow \text { memasukan } \\
\text { data }\end{array}$ & $\begin{array}{l}\text { Apabila data } \\
\text { berhasil } \\
\text { disimpan } \\
\text { database }\end{array}$ & Berhasil \\
\hline 9. & $\begin{array}{l}\text { Melakukan sifat } \\
\text { agenda }\end{array}$ & $\begin{array}{l}\text { Memilih menu sifat } \\
\text { agenda } \rightarrow \text { memilih icon } \\
\text { pensil } \rightarrow \text { melakukan edit } \\
\text { data }\end{array}$ & $\begin{array}{l}\text { Apabila data } \\
\text { berhasil di edit } \\
\text { dan data masuk } \\
\text { ke } \\
\text { database }\end{array}$ & Berhasil \\
\hline 10. & $\begin{array}{l}\text { Melakukan hapus } \\
\text { sifat agenda }\end{array}$ & $\begin{array}{l}\text { Memilih menu sifat } \\
\text { agenda } \rightarrow \text { memilih icon } \\
\text { hapus sifat agenda }\end{array}$ & $\begin{array}{l}\text { Apabila data } \\
\text { berhasil di hapus } \\
\text { sesuai dengan id }\end{array}$ & Berhasil \\
\hline 11. & $\begin{array}{l}\text { Memambahkan } \\
\text { perencanaan } \\
\text { agenda }\end{array}$ & $\begin{array}{l}\text { Memilih menu } \\
\text { perencanaan agenda } \\
\text { agenda } \rightarrow \text { memilih } \\
\text { tombol } \\
\text { create } \rightarrow \text { memasukan } \\
\text { data }\end{array}$ & $\begin{array}{l}\text { Apabila data } \\
\text { berhasil } \\
\text { disimpan } \\
\text { database }\end{array}$ & Berhasil \\
\hline 12. & Melakukan & Memilih & Apabila & Berhasil \\
\hline
\end{tabular}




\begin{tabular}{|c|c|c|c|c|}
\hline & $\begin{array}{l}\text { perencanaan } \\
\text { agenda }\end{array}$ & $\begin{array}{l}\text { perencanaan agenda } \\
\text { agenda } \rightarrow \text { memilih icon } \\
\text { pensil } \rightarrow \text { melakukan edit } \\
\text { data }\end{array}$ & $\begin{array}{l}\text { berhasil di edit } \\
\text { dan data masuk } \\
\text { ke } \\
\text { database }\end{array}$ & \\
\hline 13. & $\begin{array}{l}\text { Melakukan hapus } \\
\text { perencanaan } \\
\text { agenda }\end{array}$ & $\begin{array}{l}\text { Memilih menu } \\
\text { perencanaan agenda } \\
\text { agenda } \rightarrow \text { memilih icon } \\
\text { hapus perencanaan } \\
\text { agenda }\end{array}$ & $\begin{array}{l}\text { Apabila data } \\
\text { berhasil di hapus } \\
\text { sesuai dengan id }\end{array}$ & Berhasil \\
\hline 14. & $\begin{array}{l}\text { Memambahkan } \\
\text { pimpinan } \\
\text { rombongan } \\
\text { agenda }\end{array}$ & $\begin{array}{l}\text { Memilih menu } \\
\text { pimpinan rombongan } \\
\text { agenda } \rightarrow \text { memilih } \\
\text { tombol } \\
\text { create } \rightarrow \text { memasukan } \\
\text { data }\end{array}$ & $\begin{array}{l}\text { Apabila data } \\
\text { berhasil } \\
\text { disimpan di } \\
\text { database }\end{array}$ & Berhasil \\
\hline 15. & $\begin{array}{l}\text { Melakukan } \\
\text { pimpinan } \\
\text { rombongan } \\
\text { agenda }\end{array}$ & $\begin{array}{l}\text { Memilih menu } \\
\text { pimpinan rombongan } \\
\text { agenda } \rightarrow \text { memilih icon } \\
\text { pensil } \rightarrow \text { melakukan edit } \\
\text { data }\end{array}$ & $\begin{array}{l}\text { Apabila data } \\
\text { berhasil di edit } \\
\text { dan data masuk } \\
\text { ke dalam } \\
\text { database }\end{array}$ & Berhasil \\
\hline 16. & $\begin{array}{l}\text { Melakukan hapus } \\
\text { pimpinan } \\
\text { rombongan } \\
\text { agenda }\end{array}$ & $\begin{array}{l}\text { Memilih menu jenis } \\
\text { agenda } \rightarrow \text { memilih icon } \\
\text { hapus pimpinan } \\
\text { rombongan agenda }\end{array}$ & $\begin{array}{l}\text { Apabila data } \\
\text { berhasil di hapus } \\
\text { sesuai dengan id }\end{array}$ & Berhasil \\
\hline 17. & $\begin{array}{l}\text { Memambahkan } \\
\text { peserta agenda }\end{array}$ & $\begin{array}{l}\text { Memilih menu peserta } \\
\text { agenda } \rightarrow \text { memilih } \\
\text { tombol } \\
\text { create } \rightarrow \text { memasukan } \\
\text { data }\end{array}$ & $\begin{array}{l}\text { Apabila data } \\
\text { berhasil } \\
\text { disimpan di } \\
\text { database }\end{array}$ & Berhasil \\
\hline 18. & $\begin{array}{l}\text { Melakukan } \\
\text { peserta agenda }\end{array}$ & $\begin{array}{l}\text { Memilih menu peserta } \\
\text { agenda } \rightarrow \text { memilih icon } \\
\text { pensil } \rightarrow \text { melakukan edit } \\
\text { data }\end{array}$ & $\begin{array}{l}\text { Apabila data } \\
\text { berhasil di edit } \\
\text { dan data masuk } \\
\text { ke } \\
\text { database }\end{array}$ & Berhasil \\
\hline
\end{tabular}




\begin{tabular}{|c|c|c|c|c|}
\hline 19. & $\begin{array}{l}\text { Melakukan hapus } \\
\text { peserta agenda }\end{array}$ & $\begin{array}{l}\text { Memilih menu peserta } \\
\text { agenda } \rightarrow \text { memilih icon } \\
\text { hapus peserta agenda }\end{array}$ & $\begin{array}{l}\text { Apabila data } \\
\text { berhasil di hapus } \\
\text { sesuai dengan id }\end{array}$ & Berhasil \\
\hline 20. & $\begin{array}{l}\text { Memambahkan } \\
\text { ruang }\end{array}$ & $\begin{array}{l}\text { Memilih menu } \\
\text { ruang } \rightarrow \text { memilih } \\
\text { tombol } \\
\text { create } \rightarrow \text { memasukan } \\
\text { data }\end{array}$ & $\begin{array}{l}\text { Apabila data } \\
\text { berhasil } \\
\text { disimpan di } \\
\text { database }\end{array}$ & Berhasil \\
\hline 21. & Melakukan ruang & $\begin{array}{l}\text { Memilih } \\
\text { ruang } \rightarrow \text { memilih icon } \\
\text { pensil } \rightarrow \text { melakukan edit } \\
\text { data }\end{array}$ & $\begin{array}{l}\text { Apabila data } \\
\text { berhasil di edit } \\
\text { dan data masuk } \\
\text { ke dalam } \\
\text { database }\end{array}$ & Berhasil \\
\hline 22. & $\begin{array}{l}\text { Melakukan hapus } \\
\text { ruang }\end{array}$ & $\begin{array}{l}\text { Memilih } \\
\text { ruang } \rightarrow \text { memilih } \\
\text { hapus ruang }\end{array}$ & $\begin{array}{l}\text { Apabila data } \\
\text { berhasil di hapus } \\
\text { sesuai dengan id }\end{array}$ & Berhasil \\
\hline 23. & $\begin{array}{l}\text { Memambahkan } \\
\text { pegawai }\end{array}$ & $\begin{array}{l}\text { Memilih menu } \\
\text { pegawai } \rightarrow \text { memilih } \\
\text { tombol } \\
\text { create } \rightarrow \text { memasukan } \\
\text { data }\end{array}$ & $\begin{array}{l}\text { Apabila data } \\
\text { berhasil } \\
\text { disimpan di } \\
\text { database }\end{array}$ & Berhasil \\
\hline 24. & $\begin{array}{l}\text { Melakukan } \\
\text { pegawai }\end{array}$ & $\begin{array}{l}\text { Memilih menu } \\
\text { pegawai } \rightarrow \text { memilih } \\
\text { icon } \\
\text { pensil } \rightarrow \text { melakukan edit } \\
\text { data }\end{array}$ & $\begin{array}{lr}\text { Apabila } & \text { data } \\
\text { berhasil di edit } \\
\text { dan data masuk } \\
\text { ke } & \text { dalam } \\
\text { database } & \end{array}$ & Berhasil \\
\hline 25. & $\begin{array}{l}\text { Melakukan hapus } \\
\text { pegawai }\end{array}$ & $\begin{array}{l}\text { Memilih menu } \\
\text { pegawai } \rightarrow \text { memilih } \\
\text { icon hapus pegawai }\end{array}$ & $\begin{array}{l}\text { Apabila data } \\
\text { berhasil di hapus } \\
\text { sesuai dengan id }\end{array}$ & Berhasil \\
\hline 26. & $\begin{array}{l}\text { Memambahkan } \\
\text { jabatan }\end{array}$ & $\begin{array}{l}\text { Memilih menu } \\
\text { jabatan } \rightarrow \text { memilih } \\
\text { tombol } \\
\text { create } \rightarrow \text { memasukan } \\
\text { data }\end{array}$ & $\begin{array}{l}\text { Apabila data } \\
\text { berhasil } \\
\text { disimpan } \\
\text { database }\end{array}$ & Berhasil \\
\hline 27. & Melakukan & Memilih & Apabila & Berhasil \\
\hline
\end{tabular}




\begin{tabular}{|c|c|c|c|c|}
\hline & jabatan & $\begin{array}{l}\text { jabatan } \rightarrow \text { memilih icon } \\
\text { pensil } \rightarrow \text { melakukan edit } \\
\text { data }\end{array}$ & $\begin{array}{l}\text { berhasil di edit } \\
\text { dan data masuk } \\
\text { ke } \\
\text { database }\end{array}$ & \\
\hline 28. & $\begin{array}{l}\text { Melakukan hapus } \\
\text { jabatan }\end{array}$ & $\begin{array}{l}\text { Memilih menu } \\
\text { jabatan } \rightarrow \text { memilih icon } \\
\text { hapus jabatan }\end{array}$ & $\begin{array}{l}\text { Apabila data } \\
\text { berhasil di hapus } \\
\text { sesuai dengan id }\end{array}$ & Berhasil \\
\hline 29. & $\begin{array}{l}\text { Memambahkan } \\
\text { unit agenda }\end{array}$ & $\begin{array}{l}\text { Memilih menu unit } \\
\text { agenda } \rightarrow \text { memilih } \\
\text { tombol } \\
\text { create } \rightarrow \text { memasukan } \\
\text { data }\end{array}$ & $\begin{array}{l}\text { Apabila data } \\
\text { berhasil } \\
\text { disimpan } \\
\text { database }\end{array}$ & Berhasil \\
\hline 30. & $\begin{array}{l}\text { Melakukan unit } \\
\text { agenda }\end{array}$ & $\begin{array}{l}\text { Memilih menu unit } \\
\text { agenda } \rightarrow \text { memilih icon } \\
\text { pensil } \rightarrow \text { melakukan edit } \\
\text { data }\end{array}$ & $\begin{array}{l}\text { Apabila data } \\
\text { berhasil di edit } \\
\text { dan data masuk } \\
\text { ke } \\
\text { database }\end{array}$ & Berhasil \\
\hline 31. & $\begin{array}{l}\text { Melakukan hapus } \\
\text { unit agenda }\end{array}$ & $\begin{array}{l}\text { Memilih menu unit } \\
\text { agenda } \rightarrow \text { memilih icon } \\
\text { hapus unit }\end{array}$ & $\begin{array}{l}\text { Apabila data } \\
\text { berhasil di hapus } \\
\text { sesuai dengan id }\end{array}$ & Berhasil \\
\hline 32. & $\begin{array}{l}\text { Memambahkan } \\
\text { agenda peserta }\end{array}$ & $\begin{array}{l}\text { Memilih menu agenda } \\
\text { peserta } \rightarrow \text { memilih } \\
\text { tombol } \\
\text { create } \rightarrow \text { memasukan } \\
\text { data }\end{array}$ & $\begin{array}{l}\text { Apabila data } \\
\text { berhasil } \\
\text { disimpan di } \\
\text { database }\end{array}$ & Berhasil \\
\hline 33. & $\begin{array}{l}\text { Melakukan } \\
\text { agenda peserta }\end{array}$ & $\begin{array}{l}\text { Memilih menu agenda } \\
\text { peserta } \rightarrow \text { memilih icon } \\
\text { pensil } \rightarrow \text { melakukan edit } \\
\text { data }\end{array}$ & $\begin{array}{l}\text { Apabila data } \\
\text { berhasil di edit } \\
\text { dan data masuk } \\
\text { ke } \\
\text { database }\end{array}$ & Berhasil \\
\hline 34. & $\begin{array}{l}\text { Melakukan hapus } \\
\text { agenda peserta }\end{array}$ & $\begin{array}{l}\text { Memilih menu agenda } \\
\text { peserta } \rightarrow \text { memilih icon } \\
\text { hapus agenda peserta }\end{array}$ & $\begin{array}{l}\text { Apabila data } \\
\text { berhasil di hapus } \\
\text { sesuai dengan id }\end{array}$ & Berhasil \\
\hline 35. & Memambahkan & Memilih menu rincian & Apabila & Berhasil \\
\hline
\end{tabular}




\begin{tabular}{|c|c|c|c|c|}
\hline & $\begin{array}{ll}\text { rincian agenda } \\
\text { peserta }\end{array}$ & $\begin{array}{l}\text { agenda } \\
\text { peserta } \rightarrow \text { memilih } \\
\text { tombol } \\
\text { create } \rightarrow \text { memasukan } \\
\text { data }\end{array}$ & $\begin{array}{l}\text { berhasil } \\
\text { disimpan } \\
\text { database }\end{array}$ & \\
\hline 36. & $\begin{array}{l}\text { Melakukan } \\
\text { rincian agenda } \\
\text { peserta }\end{array}$ & $\begin{array}{l}\text { Memilih menu rincian } \\
\text { agenda } \\
\text { peserta } \rightarrow \text { memilih icon } \\
\text { pensil } \rightarrow \text { melakukan edit } \\
\text { data }\end{array}$ & $\begin{array}{lr}\text { Apabila data } \\
\text { berhasil di edit } \\
\text { dan data masuk } \\
\text { ke } \\
\text { database }\end{array}$ & Berhasil \\
\hline 37. & $\begin{array}{l}\text { Melakukan hapus } \\
\text { jenis agenda }\end{array}$ & $\begin{array}{l}\text { Memilih menu jenis } \\
\text { agenda } \rightarrow \text { memilih icon } \\
\text { hapus rincian agenda } \\
\text { peserta }\end{array}$ & $\begin{array}{l}\text { Apabila data } \\
\text { berhasil di hapus } \\
\text { sesuai dengan id }\end{array}$ & Berhasil \\
\hline 38. & $\begin{array}{l}\text { Menampilkan } \\
\text { tampilan } \\
\text { kalender }\end{array}$ & $\begin{array}{l}\text { Memilih menu } \\
\text { tampilan kalender }\end{array}$ & $\begin{array}{l}\text { Apabila kalender } \\
\text { berhasil sesuai } \\
\text { dengan hak akses }\end{array}$ & Berhasil \\
\hline 39. & $\begin{array}{l}\text { Menampilkan } \\
\text { detail tampilan } \\
\text { kalender }\end{array}$ & $\begin{array}{l}\text { Memilih menu } \\
\text { tampilan } \\
\text { kalender } \rightarrow \text { memilh } \\
\text { tanggal }\end{array}$ & $\begin{array}{lr}\text { Apabila dapat } \\
\text { menampilkan } \\
\text { detail kalender } \\
\text { sesuai dengan } \\
\text { tanggal } \\
\text { agenda }\end{array}$ & Berhasil \\
\hline 40. & $\begin{array}{l}\text { Menampilkan } \\
\text { cetak presensi }\end{array}$ & $\begin{array}{l}\text { Memilih menu rincian } \\
\text { agenda } \\
\text { peserta } \rightarrow \text { memilih } \\
\text { button cetak presensi }\end{array}$ & $\begin{array}{l}\text { Apabila berhasil } \\
\text { menampilkan } \\
\text { nama peserta } \\
\text { sesuai dengan } \\
\text { agenda } \quad \text { yang } \\
\text { diikuti }\end{array}$ & Berhasil \\
\hline 41. & $\begin{array}{l}\text { Melakukan sms } \\
\text { broadcast }\end{array}$ & $\begin{array}{l}\text { Memilih menu rincian } \\
\text { agenda } \\
\text { peserta } \rightarrow \text { memilih } \\
\text { button kirim sms }\end{array}$ & $\begin{array}{l}\text { Apabila } \\
\text { menampilkan } \\
\text { data sesuai } \\
\text { agenda dan } \\
\text { peserta }\end{array}$ & Berhasil \\
\hline 42. & Menampilkan & Memilih menu rincian & Apabila format & Berhasil \\
\hline
\end{tabular}




\begin{tabular}{|l|l|l|l|l|}
\hline format sesuai & agenda terkirim & \\
dengan sms yang & peserta $\rightarrow$ memilih & yang sesuai \\
dikehendaki & button & & \\
& sms $\rightarrow$ menampilkan \\
& form pengiriman & & \\
\hline
\end{tabular}

Gbr.12. Pengujian bagian Halaman Login

\section{KESIMPULAN}

Telah dibuat Sistem Informasi Perencanaan Agenda Pegawai UNS (Universitas Sebelas Maret) dengan Menggunakan Framework Yii2 dengan hasil yaitu Sistem ini menggunakan MySQL untuk Database Management System. Sistem ini digunakan untuk mempermudah perencanaan agenda pegawai dan dilengkapi dengan broadcast sms dengan menggunakan API UNS.Dengan hasil uji coba fungsi dari pihak operator unit dan peserta. Admin dalam hal ini ada admin sistem berfungsi menginputkan data non transaksional seperti nama pegawai, unit. Operator unit bekerja untuk menginputkan data transaksional seperti perencanaan agenda tiap tahunnya, penambahan pimpinan rombongan, mengolah peserta, dan melakukan perencanaan agenda. Sedangkan peserta melihat agenda dan detail agenda.

\section{DAFTAR PUSTAKA}

[1]Solichin, Achmad.2016. Pemrograman Web dengan PHP dan MySQL

[2]Fatansyah.1999. Basis Data. Bandung : Informatika.

[3]BOC Indonesia. 2007. Pengertian Website, Web Hosting dan Domain Name. http://www.baliorange.web.id/ [diakses pada 6 Agustus 2016]

[4]Dedi Usman. 2008. Perancangan Sistem Manajemen Informasi Berita dan Agenda Kegiatan Berbasis Website

[5]Hanif Al fatta.2007.Analisis dan Perancangan Sistem Informasi untuk Keunggulan Bersaing Perusahaan dan Organisasi Modern. Yogyakarta

[6]Masruri M. Hilmi \& Java Creativity, 2015.Membangun Sms gateway Dengan GAMMU dan Kalkun. Elex Media Komputindo, Jakarta

[7]http://www.academia.edu/7534109/Pengertian_Sistem_Menurut_Jogiyanto_H, [diakses pada 5 Agustus 2016]

[8]http://www.jejaring.web.id/mudahnya-memahami-application-programming-interface-api/ [diakses pada 6 September 2016]

[9]http://www.yiiframework.com/doc/guide/1.0/id/quickstart.what-is-yii [diakses pada 5 Agustus 2016]

[10]https://www.academia.edu/8008290/Analisis_Model_Terstruktur_dan_Analisis_Model_Berorientasi_ Object [diakses pada tanggal 6 Agustus 2016]

[11]https://simpeg.uns.ac.id/ [diakses pada 6 September 2016]

[12]kurniawan, Iwan. 2011. Perancangan dan Pengembangan Sistem Informasi Penjadwalan Ruang dan Undangan Online Berbasis Web di Fakultas Teknologi Industri Universitas Pembangunan Nasional "Veteran" Jawa Timur.

[13]Nugroho, Adi. 2009. Rekayasa Perangkat Lunak Menggunakan UML dan Java.Yogyakarta: ANDI. Sam Soleh. 2013. Pembangunan Website Sekolah SMK Islam Sudirman Kedungjati.

[14]Whitten, Jeffery L., Bentley, Lonnie D., dan Dittman, Kevin C. 2004. Metode Desain dan Analisis Sistem edisi 6. 